\title{
Refractory Peripheral T-Cell Lymphoma, Not Otherwise Specified
}

National Cancer Institute

\section{Source}

National Cancer Institute. Refractory Peripheral T-Cell Lymphoma, Not Otherwise

Specified. NCI Thesaurus. Code C9339.

Peripheral T-cell lymphoma, not otherwise specified that is resistant to treatment. 